\title{
Transmissão experimental do Grapevine virus $B$ pela cochonilha Pseudococcus longispinus Targioni-Tozzetti (Hemiptera: Pseudococcidae)
}

\author{
Hugo Kuniyuki ${ }^{1,4}$, Ricardo Gioria ${ }^{2}$, Jorge Alberto Marques Rezende ${ }^{2,4}$, Cristina Granara de Willink ${ }^{3}$, José Polese \\ Soares Novo ${ }^{1}$, Valdir Atsushi Yuki ${ }^{1}$
}

${ }^{1}$ Centro de Pesquisa e Desenvolvimento de Fitossanidade, Instituto Agronômico, CP 28, 13020-902, Campinas, SP <hkuniyuk@iac.sp.gov.br>; ${ }^{2}$ Depto. de Entomologia, Fitopatologia e Zoologia Agrícola, ESALQ/USP, CP 9, 13418-900, Piracicaba, SP.; ${ }^{3}$ Instituto Superior de Entomologia, Fac. de Ciencias Naturales, San Miguel de Tucumán, Argentina; ${ }^{4}$ Bolsistas do CNPq. Apoio PRONEX.

Data de chegada: 19/06/2004. Aceito para publicação em: 01/08/2005.

\begin{abstract}
Kuniyuki, H.; Gioria, R.; Rezende, J.A.M.; Willink, C.G.; Novo, J.P.S.; Yuki, V.A. Transmission of the Grapevine virus B by the mealybug Pseudococcus longispinus Targioni-Tozzetti (Hemiptera:Pseudococcidae) in Brazil. Summa Phytopathologica, v.32, n. 2, p.151-155, 2006.

In the State of São Paulo, Brazil, there are two isolates of Grapevine virus $B(\mathrm{GVB})$ associated with grapevine corky bark disease (GCB). Although serologically similar, they induce distinct reaction on some grape varieties. They are called GVB-C for common isolate and GVBI for isolate obtained from the variety Italia. The objective of this work was to verify the transmission of both GVB isolates from infected to healthy plants by the mealybug Pseudococcus longispinus. The transmission of the virus was determined by visual analysis of symptoms, ELISA and RT-PCR. In all transmission experiments, grape indicator plants that had been exposed to presumably viruliferous

mealybugs reacted in 8-12 months with a typical symptoms of GCB. Healthy LN-33 plants, maintained around one GCB-C affected LN33 plant, highly infested by the mealybug, became infected with incidence of $54.2 \%$ after four years. Experimental inoculation of healthy $\mathrm{LN}-33$ plants with viruliferous mealybugs resulted in infection rates of $46.2 \%$ for GVB-C and $40.0 \%$ for GVB-I, after three years. Although $P$. longispinus occurs eventually in São Paulo State vineyards, preventive control measures for this insect must be taken on areas where healthy clones of scion and rootstock varieties are maintained.
\end{abstract}

Additional keywords: grapevine corky bark, mealybug vector, virus, GVB, ELISA, RT-PCR.

\section{RESUMO}

Kuniyuki, H.; Gioria, R.; Rezende, J.A.M.; Willink, C.G.; Novo, J.P.S.; Yuki, V.A. Transmissão do Grapevine virus B pela cochonilha Pseudococcus longispinus Targioni-Tozzetti (Hemiptera:Pseudococcidae). Summa Phytopathologica, v.32, n. 2, p.151-155, 2006.

Em São Paulo, existem dois isolados do Grapevine virus B (GVB), sorologicamente semelhantes e sintomatologicamente distintos, que causam a doença denominada fendilhamento cortical ("grapevine corky bark", GCB). Na literatura estrangeira existem relatos de que o GVB pode ser transmitido por cochonilhas brancas. O objetivo do presente trabalho foi o de verificar a transmissibilidade do GVB de videira infectada para videira sadia através da cochonilha da espécie Pseudococcus longispinus. Os dois isolados do vírus foram testados: o isolado comum (GVB-C) e o isolado Itália (GVB-I). A confirmação de infecção foi feita através da análise visual de sintomas, ELISA e RTPCR. Em todos os testes de inoculação experimental, os primeiros sintomas da virose foram notados com, aproximadamente, 8 a 12 meses após a exposição às cochonilhas. Plantas sadias da variedade
LN-33, mantidas ao redor de uma planta infectada com o GVB-C e altamente infestada pela $P$. longispinus, tornaram-se infectadas com incidência de 54,2\%, após 4 anos. Empregando-se inoculação experimental com cochonilhas virulíferas, plantas da indicadora LN-33 apresentaram infecção de 46,2\% e 40,0\% para o GVB-C e GVB-I, respectivamente, após 3 anos de observações. Apesar desta espécie de cochonilha ocorrer de maneira eventual nos vinhedos do Estado de São Paulo, precauções devem ser tomadas em áreas onde são mantidos clones sadios de variedades de copa e de porta-enxerto de videira, visto que esses insetos, além de possuírem grande número de plantas hospedeiras, também podem transmitir outros importantes vírus da videira.

Palavras-chave adicionais: fendilhamento cortical da videira, "grapevine corky bark”, vírus, GVB, inseto vetor, ELISA, RT-PCR. 
O fendilhamento cortical da videira (Vitis spp.) é uma doença que ocorre comumente nos vinhedos do Estado de São Paulo (7) e em outras áreas vitícolas do Brasil (6). Vem sendo considerado semelhante à doença "grapevine corky bark" (GCB) descrita em outros países, com base nos sintomas causados na videira indicadora LN-33. Essa doença pertence ao complexo denominado lenho rugoso da videira ("grapevine rugose wood" - GRW), que é um termo usado para designar um grupo de doenças caracterizadas por causar alterações no lenho de plantas afetadas de variedades sensíveis $(3,9)$. A GCB vem sendo atribuída ao vírus B da videira (Grapevine virus B - GVB), de partículas filamentosas, flexuosas, de $12 \mathrm{~nm}$ x 800nm e pertencente ao gênero Vitivirus e à nova família Flexiviridae (1). $\mathrm{O}$ GVB é transmissível por união de tecidos com facilidade, por inoculação mecânica com dificuldade e, experimentalmente, por espécies de cochonilhas brancas ("mealybugs") (Hemiptera: Pseudococcidae) (3).

Os sintomas da doença são caracterizados na videira LN33 , na qual podem ser observadas clorose nas folhas, intumescências e rachaduras nos entre-nós dos ramos do ano, caneluras no tronco e nos ramos e redução de vigor das plantas $(5,10)$.

Em São Paulo, ocorrem dois isolados do vírus causador do GCB, que, embora sorologicamente semelhantes (9), podem ser separados através da sintomatologia. O isolado comum (GVBC) induz sintomas característicos em variedades americanas, como Niagara, Concord e Isabel (7). Já o isolado Itália (GVB-I) não causa sintomas nestas variedades e foi originalmente obtido de plantas da variedade Itália (8). Os dois isolados apresentam sintomas evidentes na indicadora LN-33. No Estado de São Paulo, o fendilhamento cortical ocorre, geralmente, com incidência de 9 a 20\%, dependendo da variedade (7). Contudo, incidências de cerca de $50 \%$ já foram observadas em plantios comerciais da variedade Niagara Branca na região de São Roque, SP. No RS, algumas plantações apresentam incidência superior a $60 \%$ (6). Apesar disso, a frequência da doença em campo é difícil de ser avaliada visualmente, pois muitas variedades de copa e de porta-enxerto não apresentam sintomas típicos ou simplesmente são assintomáticas $(5,6,7)$.

O fendilhamento cortical causa queda na produção, maturação incompleta dos ramos e dos frutos, aparente incompatibilidade entre a variedade de copa e de porta-enxerto, declínio e eventual morte das plantas. A severidade da doença é bastante variável, pois depende da combinação copa/porta-enxerto (5). A perda na produção de uva é proporcional à severidade dos sintomas e, dependendo do porta-enxerto sobre o qual a variedade está enxertada, pode haver redução de até 93,3\% (14). Embora determinações experimentais não tenham sido feitas no Brasil, as variedades mais sensíveis de V. labrusca, como Niagara Branca e Niagara Rosada, apresentam acentuada redução na produção de uva e quase nada produzem, se muito afetadas $(6,7)$.

O GVB pode ocorrer conjuntamente com outros vírus da videira, mas a formação de complexos induzindo alterações sintomatológicas ou sinergismo ainda não foi observada.

A ocorrência do GCB nos vinhedos deve-se inicialmente à propagação clonal de variedades de copa e de porta-enxerto $(5,10)$. A existência de cochonilhas que transmitem o GVB sob condições experimentais pode favorecer a posterior disseminação do vírus dentro das plantações (11). Embora não existam evidências de disseminação por vetores no Brasil, há cerca de 30 anos, na região de São Roque, SP, ouviam-se relatos de viticultores afirmando que a doença, que era chamada de "inchaço dos ramos", se alastrava lentamente dentro das plantações das variedades Isabel e Niagara Branca.

O presente trabalho teve por objetivo verificar se a cochonilha Pseudococcus longispinus, que ocorre eventualmente nos vinhedos do Estado de São Paulo, pode atuar como vetora dos isolados do GVB e, consequentemente, ter potencial importância na epidemiologia da doença dentro das plantações de uva.

\section{MATERIAL E MÉTODOS}

A espécie da cochonilha branca Pseudococcus longispinus Targioni-Tozzetti foi identificada pela taxonomista C. de Willink (Instituto Superior de Entomologia, Argentina). A fêmea adulta tem o corpo recoberto por uma secreção branca e pulverulenta, mede cerca de 3-4 mm de comprimento e apresenta apêndices filamentosos dispostos lateralmente, com um longo par na extremidade posterior. A espécie foi coletada de um cacho de uva de uma planta da variedade Itália, em Campinas, SP. A população do inseto foi multiplicada em brotos novos de tubérculos de batata (Solanum tuberosum L.) e em plantas de begônia (Begonia semperflorens Link \& Otto), mantidos em uma sala isolada do Centro de P\&D de Fitossanidade/Virologia..

As videiras sadias utilizadas foram da variedade $\mathrm{LN}-33$, indicadora universal do $\operatorname{GCB}(5,10)$, sendo todas de mesmo clone ou seja, originadas de uma mesma planta matriz. Os isolados do GVB, comum (GVB-C) e Itália (GVB-I), previamente identificados através do teste imuno-enzimático de ELISA e separados por teste biológico, foram mantidos nas videiras LN-33 e Niagara Branca, em casa de vegetação.

O teste de TAS-ELISA foi aplicado usando antissoro comercial contra o GVB (Agritest, Bari, Valenzano, Itália) e empregando-se o protocolo desenvolvido por essa empresa. A absorbância foi registrada em um leitor de ELISA ( $\sum 960$, Metertech), 2-3 horas após a incubação do substrato, no escuro, a temperatura ambiente. Uma amostra foi considerada positiva, quando o valor da absorbância foi pelo menos três vezes superior ao valor da absorbância da amostra sadia. Para testes empregando extrato de videira, foi utilizado um volume de $200 \mu \mathrm{l}$ por poço da placa de poliestireno.

Nas tentativas de transmissão de videira para videira, em casa de vegetação, iniciadas em janeiro de 2000, plantas sadias de LN-33, dispostas em cinco linhas e cinco fileiras, quatro das quais com cinco plantas e uma com quatro plantas, foram deixadas para se desenvolverem livremente até o final do ciclo vegetativo (junho/2001), ficando com os ramos entrelaçados. Outra planta, infectada pelo GVB-C e com sintomas fortes da doença, foi colocada no meio da terceira fileira e terceira linha. Essa planta estava altamente infestada pela cochonilha P. longispinus, pois foi deixada para livre colonização. As plantas foram mantidas sem aplicação de qualquer inseticida durante os 4 anos do experimento, para que o inseto presente na planta infectada pelo GVB-C colonizasse as videiras sadias, naturalmente.

Em outro experimento, iniciado em março/2000, ninfas da cochonilha foram submetidas a um período de 10 dias para a aquisição do GVB-C, deixando que se alimentassem nas plan- 
tas infectadas de LN-33, que exibiam sintomas característicos da doença. Após esse período, grupos de 10 a 15 indivíduos foram transferidos para cada uma das 35 plantas indicadoras sadias, de mesmo clone e variedade, dando-os um período de acesso à inoculação de 7 dias. As plantas sadias haviam sido previamente podadas para promover brotação nova, eliminando desta as folhas adultas ou velhas, com o propósito de depositar as cochonilhas apenas nas folhas jovens e expandidas. Em maio/2000, uma outra série de 30 plantas sadias de LN-33 foi submetida a este mesmo procedimento de inoculação para o GVB-C. Em ambos os testes, 3 grupos de 5 plantas sadias de LN-33 foram submetidas a um mesmo tratamento, porém com indivíduos sadios da cochonilha provenientes de brotos de batata, de begônia e de videira sadia da mesma variedade. Decorrido o período para transmissão, os insetos foram eliminados com inseticida.

As videiras, mantidas em áreas isoladas de casa de vegetação, foram submetidas à pulverização quinzenal com inseticida até o término dos experimentos. Observações nas plantas também foram feitas quinzenalmente, visando verificar possível ocorrência natural da cochonilha.

Em abril/2001, 15 plantas sadias de LN-33 foram submetidas a testes de transmissão do GVB-I com P. longispinus. Em maio/ 2001, outro teste foi executado, empregando 10 plantas de LN33. O procedimento de inoculação foi idêntico ao adotado para oGVB-C.

A determinação da infecção foi baseada na manifestação de sintomas na videira LN-33 e no teste de TAS-ELISA para algumas plantas de LN-33. As plantas foram observadas durante os ciclos vegetativos de 2001, 2002, 2003 e 2004, a partir de janeiro a junho de cada ano, período em que os sintomas da doença podem ser observados com nitidez em plantas mantidas em casa de vegetação.

Amostras de algumas plantas de LN-33, com e sem sintomas, foram submetidas a testes de ELISA, em junho/ 2002. As fontes de antígeno foram pecíolos e nervuras, em mistura, de folhas adultas localizadas na base dos ramos, triturados em tampão de extração $\mathrm{pH} 8.2$

A detecção do GVB em cochonilhas foi feita por RT-PCR, em junho/2003. O RNA total foi extraído de cochonilhas (virulíferas e sadias), bem como de folhas de videira e brotos de batata, separadamente, empregando a metodologia descrita por Gibbs \& Mackenzie (4). A partir do RNA total foi sintetizada a primeira fita de DNA complementar (cDNA) utilizando o primer C410 [5'-ATCAGCAAACACGCTTGAACCG-3'] (12). O cDNA foi em seguida usado em reação de PCR ("polymerase chain reaction") empregando os primers C410 e H28 [5'-GTGCTAAGAACGTCTTCACAGC-3'] (12). O regime empregado no termociclador foi de $94^{\circ} \mathrm{C}$ por 2 min, seguido de 38 ciclos de 2 min e $10 \mathrm{~s}$, sendo divididos em $30 \mathrm{~s} \mathrm{a} 94^{\circ} \mathrm{C}, 45 \mathrm{~s}$ a $52^{\circ} \mathrm{C}$ e $55 \mathrm{~s}$ a $72^{\circ} \mathrm{C}$, finalizando com $68^{\circ} \mathrm{C}$ por $7 \mathrm{~min}$. O produto da amplificação foi submetido a eletroforese em gel de agarose $1 \%$ contendo 0,5 $\mu \mathrm{g} / \mathrm{mL}$ de brometo de etídeo. A visualização do gel foi efetuada sob luz ultravioleta.

Os testes com plantas e com cochonilhas foram desenvolvidos no Centro de P\&D de Fitossanidade, setor de Virologia, do IAC, e os testes sorológicos e moleculares foram executados no Laboratório de Virologia Vegetal do Departamento de Entomologia, Fitopatologia e Zoologia Agrícola da ESALQ, Piracicaba, $\mathrm{SP}$.

\section{RESULTADOS E DISCUSSÃO}

No teste iniciado em janeiro de 2000, quando uma planta de LN-33, infectada pelo GVB-C e altamente infestada pela cochonilha, foi mantida no meio de um grupo de 24 videiras sadias, foi observado que 5 plantas apresentaram sintomas nítidos da doença em 2001, com aumento de 3 plantas em 2002, 2 plantas em 2003 e mais 3 em 2004, totalizando 13 plantas infectadas $(54,2 \%)$. O aumento anual da porcentagem de plantas infectadas deveu-se à presença da população da cochonilha nas plantas, mesmo após os ramos destas terem sido submetidos a poda de inverno. Durante a fase de dormência da videira, foram observadas massas lanuginosas debaixo da casca dos ramos e do tronco, indicando ocorrência de formas jovens e consequiente sobrevivência do inseto (15). Durante a fase vegetativa da videira era muito comum observar indivíduos, em diferentes estágios de desenvolvimento, em áreas localizadas, de folhas mais velhas da planta, indicando ter havido reprodução, e nas pontas de brotos novos, indicando movimentação dos insetos.

No primeiro ano após as tentativas de inoculação experimental do GBV-C por cochonilhas, 13 de 35 plantas da primeira repetição apresentaram sintomas perceptíveis durante a época apropriada para o aparecimento destes. No segundo ciclo vegetativo, 17 plantas apresentaram sintomas característicos da doença e esse número se manteve no terceiro ciclo vegetativo. Das 30 plantas da segunda repetição, 9 apresentaram sintomas em 2001 e 13 em 2002 e em 2003. A porcentagem média de infecção para as duas repetições foi de $46,2 \%$. As plantas sadias, onde foram colocadas cochonilhas não virulíferas, não exibiram sintomas da doença. Sete plantas de LN-33 sadias, que haviam sido inoculadas por enxertia de gema de 7 plantas de LN-33, que haviam mostrado sintomas nos testes de transmissão do GCB-C por cochonilhas em 2001, também exibiram sintomas evidentes em 2002, assim continuando em 2003. Dez outras plantas sadias de LN-33, apenas deixadas ao lado das plantas inoculadas, não mostram os sintomas da doença durante os três anos do experimento.

Três de oito plantas sadias de LN-33, que haviam sido inoculadas em junho de 2001, com cochonilhas alimentadas em uma planta que havia exibido sintomas nos testes de transmissão do GVB-C por essa espécie de inseto, executados em março de 2000, voltaram a apresentar os mesmos sintomas, sendo duas plantas em 2002 e uma em 2003.

A manifestação de sintomas em algumas videiras apenas no segundo ciclo vegetativo pode ter sido função de uma baixa concentração viral inoculada pelas cochonilhas e, portanto, insuficiente para indução de sintomas no primeiro ciclo de crescimento das plantas.

No teste de TAS-ELISA, executado apenas para amostras do segundo ciclo vegetativo de cada experimento, os resultados foram positivos para 6 plantas de LN-33 com sintomas do GCB, nos testes com GVB-C. Seis plantas assintomáticas de LN-33 foram negativas neste teste sorológico. Foram também negativos os testes feitos em 5 plantas sadias de LN-33, em brotos de 3 tubérculos de batata e 3 plantas de begônia.

Os resultados de detecção do vírus por RT-PCR nas plantas testes encontram-se na Figura 1. Um fragmento de DNA de aproximadamente $450 \mathrm{pb}$ foi amplificado de amostras das três diferentes plantas de LN-33 que exibiram sintomas característicos do GCB nos testes de transmissão por cochonilhas e de 


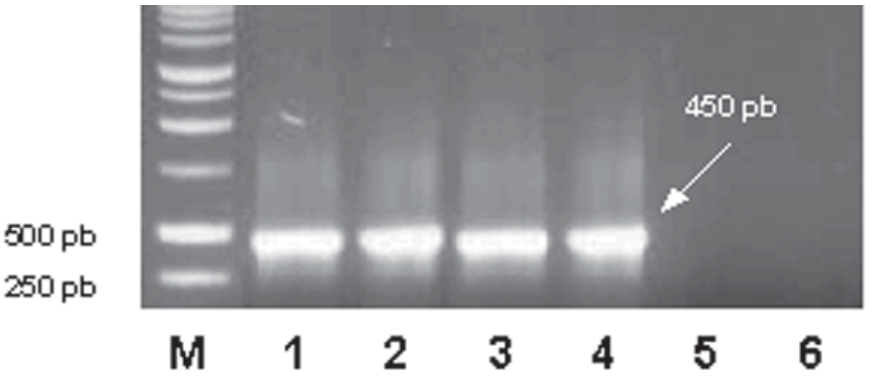

Figura 1. Fragmentos amplificados por RT-PCR, observados em gel de agarose $1 \%$, corado com brometo de etídeo. $\mathrm{M}$, marcador de peso molecular; 1 , folha de videira infectada com GVB (planta 1); 2 , folha de videira infectada com GVB (planta 2); 3, folha de videira infectada com GVB (planta 3); 4, folha de videira fonte de GVB; 5, broto de batata sadia; 6 , folha de videira sadia.

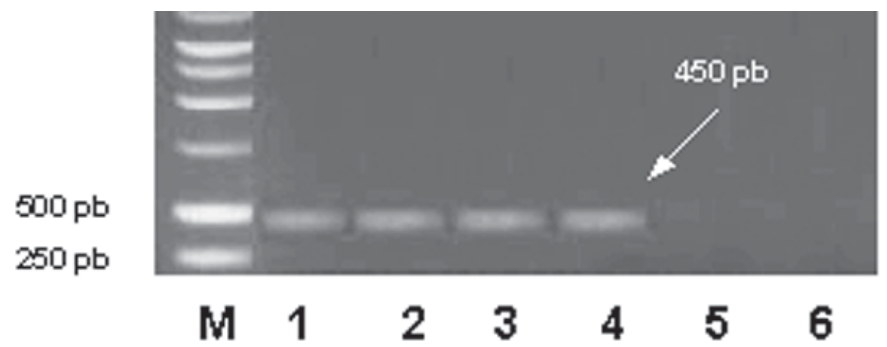

Figura 2. Fragmentos amplificados por RT-PCR, observados em gel de agarose $1 \%$, corado com brometo de etídeo. $\mathrm{M}$, marcador de peso molecular; 1 , cochonilha coletada na planta $1 ; 2$ cochonilha coletada na planta $2 ; 3$, cochonilha coletada na planta $3 ; 4$, cochonilha coletada na planta fonte de GVB; 5, cochonilha coletada de broto de batata sadia; 6 , cochonilha coletada de folha de videira sadia.

uma planta infectada de LN-33, que serviu como fonte de GVB. Essas quatro plantas apresentaram resultados positivos para GVB em testes de ELISA. No RT-PCR, não foi amplificado o produto de aproximadamente $450 \mathrm{pb}$ a partir dos extratos de videira sadia e de brotos de batata sadia, nos quais as cochonilhas sadias foram produzidas. Nos testes envolvendo o inseto vetor, um fragmento de DNA de aproximadamente $450 \mathrm{pb}$ também foi amplificado de extratos de cochonilhas alimentadas nas três plantas infectadas de LN-33 testadas acima e de cochonilhas coletadas de videira fonte de vírus (Figura 2). Extratos de cochonilhas coletadas de videira sadia e de brotos de batata sadia não apresentaram produtos de amplificação semelhantes aos detectados para cochonilhas virulíferas.

Nos experimentos com o GVB-I, 4 plantas de LN-33 de 15 testadas exibiram sintomas em 2002 e 2 em 2003, na primeira repetição. Na segunda repetição, 3 plantas exibiram sintomas de 10 testadas em 2002 e 1 em 2003. A porcentagem média de infecção para as duas repetições foi de 40,0\%. Três plantas de LN-33, inicialmente sadias, exibiram sintomas de GCB em 2003, quando foram enxertadas com gemas de três plantas que mostraram sintomas em 2002, nos testes de inoculação do GVB-I com cochonilhas. Por outro lado, três plantas sadias de Niagara Rosada, enxertadas com o mesmo material, não apre- sentaram sintomas, indicando que não houve uma possível contaminação com o GVB-C.

No teste de TAS-ELISA, aplicado nos experimentos de transmissão do GVB-I, os resultados foram positivos para amostras de 4 plantas de LN-33 com sintomas de GCB e negativos para 3 plantas sem sintomas. Foram também negativos os resultados para amostras de 3 plantas sadias de LN-33, brotos de 2 tubérculos de batata e de 2 plantas de begônia.

Os testes biológicos, de ELISA e de RT-PCR demonstraram a transmissão experimental do GVB de videira infectada para videira sadia através dessa espécie de cochonilha. Esses resultados reforçam os obtidos em outros países (11) e indicam que esse inseto pode assumir importância na epidemiologia da doença, principalmente nas regiões brasileiras onde sua ocorrência é mais comum.

Os resultados obtidos em casa de vegetação sugerem que, aparentemente, a espécie $P$. longispinus pode atuar como eficiente vetora do GVB dentro dos vinhedos. Em outros países, há relatos de disseminação natural do GVB nos vinhedos (10), sendo o aumento da incidência atribuído, mas ainda não demonstrado experimentalmente, a diversas espécies de cochonilhas, entre as quais a P. longispinus (11).

Em São Paulo, a disseminação natural desse vírus ainda não foi comprovada. Mas, há mais de trinta anos, haviam suspeitas levantadas pelos viticultores da região de São Roque, SP, de que a doença se disseminava lentamente. Aparentemente, essa observação deve ter sido verdadeira, podendo, inclusive, essa disseminação ter sido ocasionada por espécies de cochonilhas brancas, como a P. longispinus.

A importância epidemiológica dessa espécie de cochonilha pode ser grande, se a videira for mantida por muitos anos no campo, em regiões onde esse inseto ocorre mais comumente. Mesmo ocorrências ocasionais do vetor podem levar a incidências elevadas, se a cultura permanecer por longos anos no campo e se houver disponibilidade de inóculo. Assim sendo, precauções devem ser tomadas em regiões vitícolas do Brasil, principalmente nos locais onde são mantidos clones livres das principais viroses da videira, uma vez que esse inseto, além de possuir grande número de plantas hospedeiras (15), também pode transmitir o Grapevine virus A (GVA), causador da acanaladura do lenho de Kober 5BB (“Kober stem grooving”), e já existente no Brasil (2,10). O Grapevine leafroll-associated virus 5 (GLRaV-5) e o Grapevine leafroll-associated virus 9 (GLRaV-9) (13), ainda não constatados no país, também são transmitidos por essa cochonilha.

\section{REFERÊNCIAS BIBLIOGRÁFICAS}

1. Adams, M.J.; Antoniw, J.F.; Bar-Joseph, M.; Brunt, A.A.; Candresse, T.; Foster, G.D.; Martelli, G.P.; Milne, R.G.; Fauquet, C.M. The new plant virus family Flexiviridae and assessment of molecular criteria for species demarcation. Archives of Virology, Heidelberg, v.149, n.5, p.1045-1060, 2004.

2. Amorim, L.; Kuniyuki, H. Doenças da videira. In: Kimati, H.; Amorim, L.; Bergamin, A.; Camargo, L.E.A.; Rezende, J.A.M. Manual de fitopatologia: doenças de plantas cultivadas. 3.ed. São Paulo: Agronômica Ceres, 1997. v.1, cap.67, p.736-757.

3. Boscia, D.; Minafra, A.; Martelli, G.P. Filamentous viruses of the grapevine: putative trichoviruses and capilloviruses. In: Monette, P.L. (Ed.). Filamentous viruses of wood plants. Trivan- 
drum: Research Signpost. 1997. p.19-28.

4. Gibbs, A.; Mackenzie, A. A primer pair for amplifying part of the genome of all potyvirids by RT-PCR. Journal of Virological Methods, London, v.63, n.1-2, p.9-16, 1997.

5. Goheen, A.C. Corky bark. In: Pearson, R.C.; Goheen, A.C. (Eds.). Compendium of grape diseases. St. Paul: The American Phytopathological Society,1988. p.53.

6. Kuhn, G.B. Intumescimento dos ramos de videira ("corky bark"), doença constatada no Rio Grande do Sul. Fitopatologia Brasileira, Brasília, v.17, n.4, p.399-406, 1992.

7. Kuniyuki, H.; Costa, A.S. Estudos sobre a virose fendilhamento cortical da videira em São Paulo. Fitopatologia Brasileira, Brasília, v.7, n.1, p.71-78, 1982.

8. Kuniyuki, H.; Costa, A.S. Ocorrência de um isolado do vírus do fendilhamento cortical que não causa sintomas em algumas videiras americanas. Summa Phytopathologica, Jaguariúna, v.17, n.1, p.38, 1991.

9. Kuniyuki, H.; Rezende, J.A.M.; Kitajima, E.W.; Yuki, V.A.; Betti, J.A. Detecção do Grapevine virus $B$ em videiras com a doença fendilhamento cortical. Fitopatologia Brasileira, Brasília, v.25, supl., p.443, 2000.

10. Martelli, G.P. Rugose wood complex. In: Martelli, G.P. (Ed.). Graft-transmissible diseases of grapevines: handbook for detection and diagnosis. Rome: International Council for the Study of Viruses and Virus Diseases of the Grapevine / Food and Agricul- ture Organization of the United Nations, 1993. p.45-53.

11. Martelli, G.P. Grapevine virology highlights. In: Meeting of the International Council for the Study of Viruses and Virus-like Diseases of the Grapevine (ICVG), 12., 1997, Lisboa. Extended abstracts. Oeiras: Estação Agronomica Nacional, 1997. p.7-14.

12. Minafra, A.; Hadidi, A. Sensitive detection of grapevine A, B, or leafroll-associated III from viruliferous mealybugs and infected tissue by cDNA amplification. Journal of Virological Methods, London, v.47, n.1-2, p.175-188, 1994.

13. Sim, S.S.; Golino, D.A.; Rowhani, A. Experimental transmission of grapevine leafroll associated viruses types 5 and 9 by longtailed mealybugs. In: Meeting of the International Council for the Study of Viruses and Virus-like Diseases of the Grapevine (ICVG), 14., 2003, Locorotondo (Bari). Extended abstracts. Bari: University of Bari, 2003. p.210-212.

14. Tanne, E.; Dubitzky, E.; Bazak, H. Preliminary data on the effect of corky bark disease on Thompson Seedless vines grafted on various rootstocks. In: International Council for the Study of Viruses and Virus Diseases of the Grapevine, 10., 1990, Volos. Proceedings. Volos: Plant Protection Institute, 1990. p.386-389. 15. The Horticulture and Food Research of New Zealand Limited. In: Longtailed mealybug, Pseudococcus longispinus (TargioniTozzetti). Auckland, 2003. Disponível em: <http:// www.hortnet.co.nz/key/stone/info/mbl-info.htm>. Acesso em: 28 nov.2003. 